\title{
PRODUCTION HYDRAULIC PACKER FIELD TEST
}

Field Report for the period of

October 21, 1999 - November 01, 1999

Date Published: June 30, 2000

\section{Tricia Schneller, Halliburton Energy Services Jose Salas, RMOTC (PDVSA, Venezuela)}

\author{
PREPARED FOR THE U.S. DEPARTMENT OF ENERGY \\ ROCKY MOUNTAIN OILFELD TESTING CENTER
}

Work Performed Under Rocky Mountain Oilfield Testing Center (RMOTC) CRADA No. 2000-001

\section{PROTECTED CRADA INFORMATION}

This product contains Protected CRADA Information which was produced on June 30, 2000 under CRADA No. 2000-001 and is not to be further disclosed for a period of 5 years from the date it was produced except as expressly provided for in the CRADA.

Distribution E. Further dissemination authorized to the Department of Energy only; other requests shall be approved by the originating facility of higher DOE programmatic authority.

\section{Approval:}

RMOTC Manager

Date: 


\section{Disclaimer}

This report was prepared as an account of work sponsored by an agency of the United States Government. Neither the United States Government nor any agency thereof, nor any of their employees, nor any of their contractors, subcontractors, or their employees makes any warranty, express or implied, or assumes any legal liability or responsibility for the accuracy, completeness, or any third party's use or the results of such use of any information, apparatus, product, or process disclosed, or represents that its use would not infringe privately owned rights. Reference herein to any specific commercial product, process, or service by trade name, trademark, manufacturer, or otherwise does not necessarily constitute or imply its endorsement, recommendation, or favoring by the United States Government or any agency thereof, or its contractors or subcontractors. The views and opinions of authors expressed herein do not necessarily state or reflect those of the United States Government or any agency thereof. 
PRODUCTION HYDRAULIC PACKER FIELD TEST

DOE CRADA No. 2000-001

Rocky Mountain Oilfield Testing Center

907 N. Poplar, Suite 150

Casper, WY 82601

(307) 261-5000

Report Date:

Contract Date:

Completion Date:

DOE Funding:

Project Manager:

Project Engineer:

Other Major Contributors:

Contracting Officer's Representative: Barbara Tucker

RMOTC Report Number
June 30, 2000

October 12, 1999

November 1, 1999

$\$ 77,276$

Douglas Tunison

Jose Salas

Ralph Schulte 


\section{Abstract}

In October 1999, the Rocky Mountain Oilfield Testing Center and the test client cooperated on a field test of new Production Hydraulic Packer technology on Well 46-TPX-10 at Naval Petroleum Reserve No. 3 near Casper, WY. Performance of the packer was evaluated in set and unset operations. The packer ability to seal the annulus between the casing and tubing was hydraulically tested and the results were recorded. 


\section{TABLE OF CONTENTS}

INTRODUCTION

WELL INFORMATION SUMMARY 2

DESCRIPTION OF THE TECHNOLOGY TESTED 2

APPLICATION POTENCIAL OF THE TECHNOLOGY 3

GENERAL NOTES OF THE TEST 3

DAILY ACTIVITIES SUMMARY 5

21-October-99 5

$\begin{array}{ll}\text { 25-October-99 } & 6\end{array}$

$\begin{array}{ll}\text { 26-October-99 } & 7\end{array}$

$\begin{array}{ll}27-O c t o b e r-99 & 8\end{array}$

28-October-99 9

$\begin{array}{lr}\text { 29-October-99 } & 10\end{array}$

$\begin{array}{ll}\text { 1-November-99 } & 10\end{array}$

$\begin{array}{ll}\text { ACTUAL TEST COST } & 10\end{array}$

TECHNICAL RESULTS OF THE TEST 


\section{Introduction}

Hydraulic production packers are a mechanical device used to complete oil and-gas wells in order to isolate different production zones from each other or the rest of the wellbore. The availability of various types and sizes allows engineers to design their wells according to their individual requirements and cost effectiveness.

The client developed a new type of production packer that uses an unconventional setting procedure, which has to be tested before going to the market. Based upon the requirements for packer design, a field test was designed to run a packer in a well, and test the ability of the packer to be set and unset, as well as its sealing capability under pressure differentials.

The test well was selected to provide a real well environment required for this particular packer. These conditions included a well about 5,000 ft deep, and cased with 7 inch casing, with fresh water as a completion fluid. 


\section{WELL INFORMATION SUMMARY}

Well Name

API Number

Lease

\#3

Field

County, State

Ground Level

Kelly Bushing

Surface Location

Surface Coordinates

Total Depth
46-TPX-10

049-025-22770

Naval Petroleum Reserve

Teapot Dome

Natrona County, Wyoming

5258

5268

Sec. 10, T-38N, R-78W

'FSL,' FWL

$5630 \mathrm{ft}$

\section{DESCRIPTION OF THE TECHNOLOGY TESTED}

RMOTC's test partner developed a new system for the remote, interventionless actuation of downhole completion equipment. Conventional methods to set Production Hydraulic Packers employ a dropped or circular ball, coiled tubing, or slickline to run a tubing or casing plug. The new system provides a safe, reliable and more cost effective alternative to the conventional intervention. It is based on a newly developed acoustic telemetry that uses the tubular fluid to propagate a predetermined pressure pulse sequence. Upon the successful detection and decoding of the pressure pulses by a downhole electronic module, a command is 
issued to activate the setting of a Production Packer. An unlimited number of packer or other hydraulically activated devices can be remotely activated in any desired sequence.

\section{APPLICATION POTENTIAL OF THE TECHNOLOGY}

The new technology developed decreases the time to set Production Hydraulic Packers and extends the operating depths to deep, highly deviated or horizontal offshore environments. Since the new system eliminates the need to circulate a ball downhole to set the service tool, a constant hydrostatic pressure can be maintained decreasing the risk of formation collapse, fluid losses and formation damage.

\section{GENERAL NOTES ON THE TEST}

The following information is designed to provide a general idea of the Production Hydraulic Packer test performed in the well 46-TPX-10 at the NPR-3 lease. This test was affected by unexpected situations during testing operations.

1. Field operations started on October 21, 1999. It was planned to conduct the test in two phases. The first phase was designed to accomplish the requirements or minimum conditions regarding well conditions needed to run the packers. This phase took four days, which exceeded the planned time for this task of two and half days. The second phase was designed to perform the packer test, which consisted of running the packer, setting the packer, hydraulically testing the annular seal, and unsetting the packer. This phase took three days, as planned. 
2. During tripping in, the casing scraper and bit would stack out (i.e., lose string weight). At this point, the operator would work the pipe by applying approximately $4-6,000 \mathrm{lbs}$ of set down weight and circulating the hole. The pipe would gain weight indicating that the obstruction had been washed out from around the bit and scraper. The pipe would then be lowered and often encountered another obstruction, a few feet lower. The process would then be repeated.

The condition of the wellbore was unknown; it had not been entered since the client's prior test in October 1998. The heavy mud (i.e., $12.7 \mathrm{ppg}$ ) used during the previous test was left in the wellbore in anticipation that the client or another service company would require the heavier mud again. The mud even in the liquid environment of the casing appeared to form rings along the inside diameter of the casing. The exact nature or cause of these rings is still debatable; however, the result was additional workover time was required to reach the bottom.

3. Despite the first phase being completed when we reached the bottom of the well, the condition of the well remained poor. Heavy mud was left in the hole and the test was affected as follows:

a. The test was planned for a dual packer run in order to simulate a multiple sand completion and test the ability of the packers to be selectively set. Since the clean up process was ineffective, and the casing scraper wasn't dressed properly for 7" 20\# casing (scraper undergage due to wear), there was a potential risk of stuck pipe due to the mud solidification around the casing wall. Therefore, the test partner decided to run only one packer, instead of two as originally planned. 
b. As part of the test a polymer pill had to be pumped into the well and placed five hundred feet above the packer. However, due to the heavy mud left in the hole the pill reversed back up to 2,500 $\mathrm{ft}$ above the packer, because of the hydrostatic underbalance caused by the heavy mud in the casing annulus. This "U-tube" effect produced thirteen barrels of backflow from the tubing.

c. Finally the test was performed and the test partner was able to establish communication through the pill and set the packer.

\section{DAILY ACTIVITIES SUMMARY}

Thursday, 10-21-99

\begin{tabular}{|l|l|l|l|}
\hline Start & Finish & Duration & Activity \\
\hline $7: 00$ & $9: 30$ & 2.5 & $\begin{array}{l}\text { Ran in the hole with 2-7/8" tubing, casing scraper, and } \\
\text { bit to 3,832' without problems. }\end{array}$ \\
\hline $9: 30$ & $12: 00$ & 2.5 & $\begin{array}{l}\text { Tagged fill at 3,832'. Pumped water into the hole with } \\
\text { water truck, took } 64 \text { bbl down tubing to see mud in } \\
\text { returns. Washed down to 3,900'. }\end{array}$ \\
\hline $12: 00$ & $5: 00$ & 5 & $\begin{array}{l}\text { Washed down to 4,178. There was still gray water } \\
\text { coming out of the hole. }\end{array}$ \\
\hline $5: 00$ & $6: 00$ & 1 & $\begin{array}{l}\text { Picked up one stand and tagged approximately 1-1/2 } \\
\text { joints in on this stand. Shut down workover unit for } \\
\text { weekend. }\end{array}$ \\
\hline
\end{tabular}


Monday, 10-25-99

\begin{tabular}{|c|c|c|c|}
\hline Start & Finish & Duration & Activity \\
\hline 7:00 & $11: 00$ & 4 & $\begin{array}{l}\text { Tagged up halfway in on joint number } 132 \text {, } \\
\text { approximately } 20 \text { ' higher than Thursday afternoon. } \\
\text { Current depth } 4,250 \text { '. Could not get deeper due to } \\
\text { insufficient pump rate. Decided to use maximum water } \\
\text { truck pumping rate available, approximately } 2 \mathrm{bbl} / \mathrm{min} \text {. } \\
\text { Calculated annular velocity at this rate to be } 65 \mathrm{ft} / \mathrm{min} \text {. } \\
\text { Need a minimum of } 150 \mathrm{ft} / \mathrm{min} \text {. to clean out hole with } \\
\text { clear water. Tried to start up circulating unit to get more } \\
\text { rate. Would not start. Rigged up stripping head to } \\
\text { reverse circulate. }\end{array}$ \\
\hline $11: 00$ & 4:00 & 5 & $\begin{array}{l}\text { Washed down to } 4,300 \text { 'at a rate of six minutes per } \\
\text { joint. Received orders to stop reverse circulating. }\end{array}$ \\
\hline 5:00 & $5: 30$ & 0.5 & $\begin{array}{l}\text { The drive line broke on the water truck. Tried to find } \\
\text { another water truck without success. Decided to } \\
\text { suspend operations until next day. }\end{array}$ \\
\hline
\end{tabular}


Tuesday, 10-26-99

\begin{tabular}{|c|c|c|c|}
\hline Start & Finish & Duration & Activity \\
\hline 7:00 & 8:00 & 1 & $\begin{array}{l}\text { Ran in the hole to } 4,300 \text { ' without problems. Contract } \\
\text { water truck arrived at the location. }\end{array}$ \\
\hline 8:00 & 9:00 & 1 & $\begin{array}{l}\text { Washed down to } 4,434 \text { '. Started up circulating unit, but } \\
\text { received orders not to use it. }\end{array}$ \\
\hline 9:00 & 9:15 & 0.25 & RIH without circulation from 4434 ' to 4591 ' (5 joints) \\
\hline 9:15 & 10:00 & 0.75 & Washed down slowly with water truck due to fill. \\
\hline 10:00 & 11:00 & 1 & RIH without circulation until top of bridge plug at 5,332 ' \\
\hline 11:00 & 1:00 & 2 & Circulating approximately 2 bbls/min. \\
\hline 1:00 & 2:15 & 1.25 & $\begin{array}{l}\text { Working on the wellhead. Contract water truck left } \\
\text { location. }\end{array}$ \\
\hline $2: 15$ & 3:30 & 1.25 & $\begin{array}{l}\text { Tripped out of the hole with } 2-7 / 8 \text { " tubing, scraper and } \\
\text { bit from } 5,332 \text { ' to surface. The clients' equipment } \\
\text { arrived on location at 2:15 PM. The winch truck was } \\
\text { used for } 15 \text { minutes to unload the equipment. The } \\
\text { vacuum truck was hauling water from the pit. }\end{array}$ \\
\hline 3:30 & 6:30 & 3 & $\begin{array}{l}\text { Tried to install a 3,000 psi wellhead, but could not break } \\
\text { out old wellhead. Installed new nipples and valves on } \\
\text { old wellhead. The Blowout Preventers (BOP's) were } \\
\text { tested with } 1,500 \text { psi for five minutes with the circulating } \\
\text { unit since the water truck could not reach the pressure } \\
\text { required. }\end{array}$ \\
\hline 6:30 & 7:00 & 0.5 & $\begin{array}{l}\text { Picked up the clients' equipment (packers) using winch } \\
\text { truck. }\end{array}$ \\
\hline
\end{tabular}


Wednesday 10-27-99

\begin{tabular}{|c|c|c|c|}
\hline Start & Finish & Duration & Activity \\
\hline 7:00 & $8: 30$ & 1.5 & $\begin{array}{l}\text { Rigged up tubing tongs and elevator with the winch } \\
\text { truck. }\end{array}$ \\
\hline 8:30 & 9:00 & 0.5 & Waited for 3-1/2" slip-type tubing elevators. \\
\hline 9:00 & 9:45 & 0.75 & Picked up packer. \\
\hline 9:45 & $1: 30$ & 3.75 & Ran in the hole with packer to 5,200 . \\
\hline $1: 30$ & $1: 45$ & 0.25 & $\begin{array}{l}\text { Rigged up packer setting equipment. Mixed extender } \\
\text { gel pill. Held pre-job safety meeting. }\end{array}$ \\
\hline $1: 45$ & 4:15 & 3.5 & $\begin{array}{l}\text { Finished mixing extender gel pill. Rigged up truck } \\
\text { pumping line and performed hydrostatic test with } 1,500 \\
\text { psi for five minutes. Pumped } 5.8 \text { bbl pill and } 25 \text { barrels } \\
\text { of water to displace pill. } U \text { tube differential pressure of } \\
250 \text { psi was found on the tubing, indicating that the hole } \\
\text { was not cleaned of the heavy mud. Opened the valve } \\
\text { on the tubing and the well back flowed } 13 \text { barrels of } \\
\text { water to equalize. The annulus still contained heavy } \\
\text { mud. }\end{array}$ \\
\hline $4: 15$ & 5:45 & 1.5 & $\begin{array}{l}\text { Tried to set packer without success. Tried again with } \\
\text { more pressure. Pick up one foot and gained tension, } \\
\text { indicating packer was set. }\end{array}$ \\
\hline $5: 45$ & 6:00 & 0.25 & $\begin{array}{l}\text { Performed packer test. Held 1,200 psi on casing } \\
\text { annulus, indicating a hydraulic seal was attained. }\end{array}$ \\
\hline 6:00 & $6: 30$ & 0.5 & $\begin{array}{l}\text { Performed client unset procedure twice withou } \\
\text { success. }\end{array}$ \\
\hline
\end{tabular}


Thursday 10-28-99

\begin{tabular}{|l|l|l|l|}
\hline Start & Finish & Duration & Activity \\
\hline 7:00 & $10: 00$ & 3 & $\begin{array}{l}\text { Dropped ball and applied pressure to release packer. } \\
\text { Tested packer. It was still set. Tried again to release } \\
\text { packer and succeeded. }\end{array}$ \\
\hline $10: 00$ & $10: 15$ & 0.25 & Reversed circulation to recover ball. Ran out of water. \\
\hline $10: 15$ & $10: 45$ & 0.5 & $\begin{array}{l}\text { Waiting for water truck. Contract water truck left } \\
\text { location. }\end{array}$ \\
\hline $10: 45$ & $1: 30$ & 2.5 & $\begin{array}{l}\text { Reversed ball out and pulled out of hole with 27/8" } \\
\text { string. }\end{array}$ \\
\hline $1: 30$ & $6: 00$ & 4.5 & $\begin{array}{l}\text { Picked up another packer and ran in the hole to 5,100'. } \\
\text { Tried to set the packer several times without success. } \\
\text { Decided to pull out of the hole with packer. }\end{array}$ \\
\hline
\end{tabular}


Friday 10-29-99

\begin{tabular}{|l|l|l|l|}
\hline Start & Finish & Duration & Activity \\
\hline $7: 00$ & $10: 30$ & 3.5 & $\begin{array}{l}\text { Finished tripping out of the hole with packer. Packer not } \\
\text { there. }\end{array}$ \\
\hline $10: 30$ & $12: 30$ & 2 & $\begin{array}{l}\text { Picked up packer fishing tool and ran in the hole to } \\
\text { recover packer. }\end{array}$ \\
\hline $12: 30$ & $1: 30$ & 1 & Problems trying to recover packer. Finally packer unset. \\
\hline $1: 30$ & $3: 00$ & 2.5 & Tripped out of the hole with fishing tool and packer. \\
\hline $3: 00$ & $3: 30$ & 0.5 & Laid down packer and shut down workover unit. \\
\hline
\end{tabular}

Monday, 11-01-99

\begin{tabular}{|l|l|l|l|}
\hline Start & Finish & Duration & Activity \\
\hline $7: 00$ & $12: 00$ & 5 & $\begin{array}{l}\text { Ran in the hole with the work string to break down } \\
\text { singles. Break down 2-7/8" tubing and shut down } \\
\text { workover unit. }\end{array}$ \\
\hline
\end{tabular}

\section{ACTUAL TEST COST}

The total cost associated with mobilization, well preparation, and field-testing, and mobilization of personnel, materials, equipment and services necessary to conduct the test is $\$ 77,276.02$. 


\section{TECHNICAL RESULTS OF THE TEST}

- Tests conducted during the week of October $25-29,1999$, confirmed the successful operation of the new system, and revealed some areas for improvement.

- A minor problem in the surface air gun control program that sets the timing of the acoustic signal sent through the tubular content was discovered.

- Inconsistencies in the functioning of a new version of the firmware were also identified.

- Built-in redundancy provided by the contingency setting method, improves overall reliability performance. 